\title{
一編 集 公 告
}

第27巻第3号の編集について

第20回大会時の公告 双び27巻 2 号の会務公告によつて 公けにした如く，本号から新らしい編集方針によつて新 らしい編集委員が編集を行つた。

前牛を $\mathrm{B}$ 群, 後牛を $\mathrm{A}$ 群の緛集委貣が担当したもので ある。但し $\mathrm{A}$ 群のうち多田治夫，伊東三四両氏の論文は
在来の編集による手持ち原稿を便宜的に組み达んだもの である。

何新らしい編集方釬による審香に著しく時間を必要と した為に本号の発刊は著しく遅れたが次号以後道々正常 に居る予定である。

「心理学研究」正誤訂正

27 巻 2 号 資料, 早大生理心理実験室

$$
\begin{aligned}
& \text { 頁行 誤 } \therefore \text { 正 } \\
& 126 \text { 下から } \text { 左 }^{\text {势 }}, \Delta \mathrm{e}=\left(\frac{\mathrm{R}_{3}}{\mathrm{R}_{1}+\mathrm{R}_{3}} \sim \frac{\mathrm{R}_{x} \pm \Delta \mathrm{R}_{x}}{\mathrm{R}_{2}+\mathrm{R}_{x} \pm \Delta \mathrm{R}_{x}}\right) \\
& \Delta \mathrm{e}=\left(\frac{\mathrm{R}_{3}}{\mathrm{R}_{1}+\mathrm{R}_{3}} \sim \frac{\mathrm{R}_{x} \pm \Delta \mathrm{R}_{x}}{\mathrm{R}_{2}+\mathrm{R}_{x} \pm \Delta \mathrm{R}_{x}}\right) \mathbf{E}
\end{aligned}
$$

\section{野上論交}

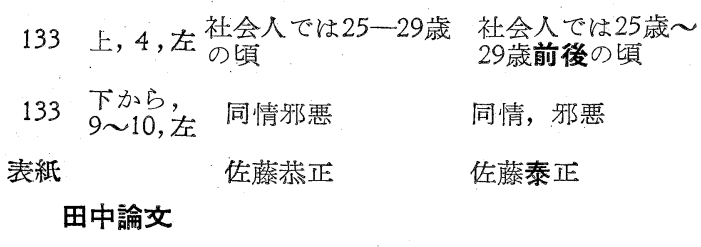

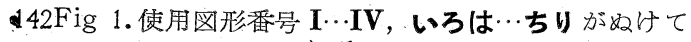

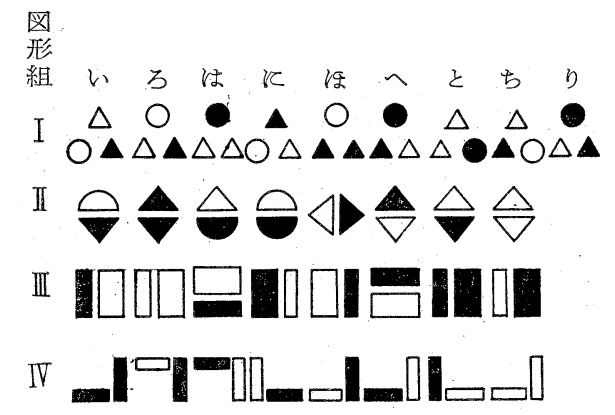

高杉論交 誤 正

152 左上図 Fig Curves of Fig 3 Curves of 下から Fig 1 は 左 Fig 1 とは

\section{・市川論交}

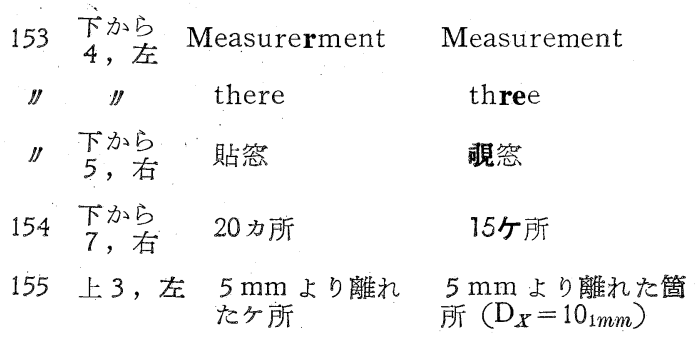

